\title{
Assessment of Criminal Charges Brought Against Teachers*
}

\begin{tabular}{ccc}
\hline $\begin{array}{c}\text { ArticleType } \\
\text { Research }\end{array}$ & Received Date & Accepted Date \\
& 21.11 .2018 & 25.09 .2019 \\
\hline & & \\
& Meltem Ökdem &
\end{tabular}

\begin{abstract}
The aim of this study was to assess the charges brought against teachers in criminal courts in Turkey. A qualitative research method was used in the study. The study used the document analysis method because it involved the study of legal documents. In order to determine what cases against teachers were brought to trial between 2004 and 2018, charges filed against teachers were obtained via www.kazanci.com and www.LegalBank.com._databases. The themes in the study were determined in accordance with the Turkish Criminal Law as crimes against the person, crimes against the nation and the state, and crimes against society. The study was initiated as a result of the fact that cases of violence in schools have increased rapidly in recent years. One factor in this is offenses committed by teachers, and this situation will cause grave social problems in the future if no measures are taken. It was found that most charges brought against teachers in the criminal courts were cases related to crimes against the person. This was followed by crimes against the nation and state and crimes against society. The curriculum of Faculties of Education should include courses such as human rights, education law, anger control and conflict management to raise teachers' awareness of these issues.
\end{abstract}

Keywords: Illegal acts, crime, punishment, teachers.

\footnotetext{
${ }^{*}$ Asummary of this study was presented at the Second International Education Research and Teacher Education Congress, 13-15 September 2018, Kuşadası, Turkiye.

** Assist. Prof. Dr., Vocational School of Justice, Çankaya University, Ankara, Turkey. E-mail: meltem@cankaya.edu.tr https://orcid.org/0000-0002-9155-6922
} 


\title{
Öğretmenlerin Ceza Mahkemelerine İntikal Eden Fiillerinin Değerlendirilmesi*
}

\begin{tabular}{ccc}
\hline $\begin{array}{c}\text { Makale Türü } \\
\text { Araştırma }\end{array}$ & Başvuru Tarihi & Kabul Tarihi \\
21.11 .2018 & 25.09 .2019 \\
& \\
& Meltem Ökdem &
\end{tabular}

\begin{abstract}
$\ddot{O} \mathbf{z}$
$\mathrm{Bu}$ araștırmanın amacı öğretmenlerin ceza mahkemelerine intikal eden fiillerinin değerlendirilmesidir. $\mathrm{Bu}$ araştırma doküman analiz modeline dayalı bir araştırmadır. $\mathrm{Bu}$ çalışmada 2004-2018 yılları arasında öğretmenlerin ceza mahkemelerine intikal eden fiillerini tespit etmek üzere, www.kazancı.com ve www.LegalBank.com veri tabanlarından öğretmenler hakkında açılan davalara ulaşılmıştır. Bu araştırmada temalar Türk Ceza Kanuna uygun olarak oluşturulmuş olup kişiye karşı suçlar, millete ve devlete karşı suçlar, topluma karşı suçlar olarak belirlenmiştir. $\mathrm{Bu}$ araştırmanın yapılma nedeni son yıllarda okullarda şiddet olaylarının hızla artmasıdır. Bunun bir nedeni de ögretmenlerin saldırgan davranışlarıdır ve bu durum önlem alınmadığı takdirde gelecekte çok büyük toplumsal yapıda büyük yaralara neden olacaktır. Sonuç olarak öğretmenler hakkında ceza mahkemelerinde görülen davalar kapsamında en fazla kişiye karşı suçlarla ilgili davaların yer aldığı görülmüş̧ür. Bunu millete ve devlete karşı suçlar ve topluma karşı suçlar izlemektedir. Okullarda öğretmenlerin öğrencilere şiddet uyguladığı ve çocukların cinsel istismara uğradığı da görülmüştür. Eğitim fakültelerinde insan hakları, eğitim hukuku, öfke kontrolü, çatışma yönetimi gibi dersler konularak öğretmenler bu konularda bilinçli hale getirilmelidir. Hizmet içi eğitim ile insan ve çocuk hakları konusunda öğretmenler bilinçlendirilmeli ve bu konulardaki farkındalığı artırılmalıdır. Okullarda rehberlik bölümü iyi çalışıp bu konuda öğrencilere gerekli desteği sağlamalıdır.
\end{abstract}

Anahtar Sözcükler: Hukuka aykıı davranışlar, suç, ceza, öğretmen.

\footnotetext{
* Bu makale 13-15 Eylül 2018 tarihinde II. International Education Research and Teacher Education Congress 'de bildiri olarak sunulmuștur.

${ }_{* * *}^{*}$ Dr. Öğgr. Üyesi, Çankaya Universitesi Adalet MYO. .E-posta: meltem@ cankaya.edu.tr., https://orcid.org/0000-0002-91556922
} 


\section{Introduction}

Teaching is one of the oldest, most sacred and important professions in human history. It is the duty of teachers to teach people what to do and not to do, and to teach the difference between good and bad, and right and wrong. Teachers have a very important role in ensuring that a child becomes a decent, honest, well-behaved and well-qualified person. But, as we learn from research or hear from the media and people around us, teachers may also be responsible for beatings, violence and other punitive acts. In other words, some teachers, who are supposed to protect and care for children, act against the core values of their profession. This research assessed the official legal documents relating to teachers who exhibited such behaviors, and, in particular, when they engaged in behaviors that were criminal. A first step was to define the concept of 'crime.'

\section{Crime}

Çopur (2015) defined crime as follows: "Crime is the actions that the law punishes or the acts and behaviors that are accepted and clearly defined by the legislative as being harmful and dangerous to society." Crime is a multifaceted concept, and has thus been the subject of many areas of study. Crime is defined in Turkish Penal Code as "an act punishable by law"; but the concept of crime varies according to many variables such as location, time and social structure (Çopur, 2015).

Crime includes many different acts, such as theft, robbery, assault, rape and murder. These acts suggest that the offender occupies a position at which criminal law and moral determinations intersect. However, disorderly conduct is not always considered a crime.

When the crime committed in Turkey is examined (Demirbaş, 2016), the main offences are homicide $(28,996)$, attempted murder $(1.821)$, sex crimes $(15,226)$, fraud $(5890)$, theft $(42,589)$, forgery $(8,874)$, drugs $(35,385)$, plunder or extortion $(22,881)$ and bodily harm $(23,287)$. These figures are for 10 of the crimes committed or allegedly committed by prisoners and convicted prisoners who were in penal institutions in 2016. As is seen, these figures are substantial (Demirbaş, 2016).

People can commit crimes for many reasons. The importance of a crime is determined by its harm to the victim and society and by whether the perpetrator committed itintentionally or not (Soyaslan, 1996). Several studies have been conducted on factors affecting crime. Among these are economic, demographic, situational, social and cultural factors (Ayhan \& Çubukçu, 2007). Various studies exist on this subject (Yıldırım, 2014; Doğan, 2011). Research has identified migration, war, poverty, unemployment, lack of awareness, irregular urbanization patterns, social deterioration, lack of respect for human dignity as the causes of crime (Menteşe, 2012).

\section{Potentially Criminal Aggressive Behavior of Teachers in Schools}

Acts of aggression can become criminal if no measures are taken and aggressiveness is a major problem both in schools and in social life in general (Carney, 2000; Smith, Morita, Jungler-Tas, Olweus, Catalano \& Sleeve, 1999; Sullivan \& Farrell, 1999). There is no official statistical data regarding aggression in schools Turkey; however, scientific studies show that the amount of aggressive behavior in schools should not be ignored (Alikaşifoğlu, Erginöz, Ercan, Uysal, Kaymak \& İlter, 2004; Ögel, Tarı \& Eke, 2005; Şahan, 2007). Since the incidence of violent acts in schools has been increasing in recent years, more attention has been directed to this issue and the prevention and reduction of violence in schools hasbecome the subject of current studies. As emphasized in the "Intergenerational Transfer" theory, aggression and violence are learned behaviors, and if no measures are taken, they can cause irreversible problems in the social structure (Ayan, 2007).Families and teachers play an important role in children' acquisition of positive social behaviors and the development and maintenance of healthy relationships in society during the childrearing process. Children model themselves on their parents and then their teachers while growing; therefore, parents and teachers should be positive role models (Gençoğlu, 2014). However, as seen in the literature, teachers may exhibit aggressive behaviors toward students (Doğan, 2000; Çetin \& Demirkasımoğlu, 2015; Mahiroğlu \& Buluç, 2013; Gömleksiz, Kilimci, Vural, Demir, Meek \& Erdal, 2008). Studies have investigated the behaviors of teachers toward students and reported on those acts brought before the courts and that create major trauma for students. One of these studies on teachers' behaviors was conducted by Doğan (2000). In this study, conducted on 50,473 children between the age of $4-12$, it was found that $62.6 \%$ of the children had been exposed to physical 
punishment In another study conducted by Mahiroğlu and Buluç (2003), 59.5\% of university students stated that they were subjected to physical punishment during their secondary education and that $51.8 \%$ of these punishments were imposed by school principals and assistant principals. According to the findings of research conducted by the Education and Science Workers' Union (Eğitim-Sen) (2003), teachers physically beat students in $40 \%$ of schools. In the Marmara and Eastern Anatolia regions, hair cutting punishments were imposed in $20 \%$ of schools,administrators reprimanded students in $66.80 \%$ of schools and teachers reprimanded students in $73.40 \%$ of the schools, and $30 \%$ of teachers and administrators carried a rod for corporal punishment in the school. According to the research, administrators beat students in $28.4 \%$ of schools. Beatings by teachers were most common in the Mediterranean region with 49\%, and the Eastern Anatolia region with 46.5\%. In the Marmara region, $37.5 \%$ of the teachers resorted to violence, while this percentage was $29 \%$ in Central Anatolia ( ).Criminal actions in schools impede education and training and damages the atmosphere in school (Uzbaş, 2009). Criminal action in a school may include intentional actions such as physical and psychological violence, as well as theft and damage to property. The mental health of children and adolescents exposed to violence may be impaired.

Gömleksiz, Kilimci, Vural,Demir, Meek\& Erdal (2008) examined teachers' behavior towards students in the schoolyard from the perspective of children's rights. The results are deeply thoughtprovoking: it was determined that teachers used penalties incompatible with human dignity during assemblies. During the assemblies, some of the teachers pushed and shouted at the students to bring them into line and to be silent, shoved them, engaged in behaviors such as hitting, punching and kicking, and remained insensitive towards violence between students. In addition, it was found that during breaks they hit students with canes, rebuked them, and engaged in behaviors such as pushing, kicking and slapping them. The students accepted as natural the physical punishment imposed on them considered beatings to be disciplinary tools. It was determined that verbal and non-verbal violence were used more frequently in schools with a lower socio-economic level.

The purpose of this study is to determine the number and type of crimes committed by teachers, who should be responsible for maintaining an environment of trust in schools ,between 2004 and 2018 by examining legal documents and court records. This research is important in determining how well teachers, who are responsible for educating the citizens of the future, abide by the law. No prior study could be found investigating the behavior of teachers tried in criminal courts. The criminal offenses committed by teachers will be classified using the Turkish Criminal Law no. 5237.

\section{Purpose}

This study aimed to evaluate charges of criminal offenses committed by teachers that were heard in the courts between 2004 and 2018.

1) How many case involving teachers as the defendant were there?

2) How were these distributed by year?

3) What kinds of crimes did the teachers commit?

\section{Method}

In this study, the qualitative research method was preferred. In cases where observation and interview are not possible in qualitative research, written and visual materials are also studied beside these methods or with these methods. The "document review" method was used in this study to examine legal judgments. In this method, written materials with information on the subject to be investigated are examined (Yıldırım and Şimşek, 2016).

\section{Data Collection}

In thed study, in order to determine which acts of teachers had been tried in criminal courts between 2004 and 2018, legal complaints filed against teachers were obtained via the www.kazanci.com and www.LegalBank.com databases. The keywords "teacher" and "school" were used in the databases' search engines. Cases between 2004-2018 were scanned and 403 criminal cases and 757 civil lawsuits were found. Civil proceedings were not included in the scope of the study and only criminal cases were 
included. 403 criminal cases were examined and 66 of them were determined to meet the inclusion criteria and were included in the research.The reason for beginning the investigation of the cases from 2004 was that the Turkish Criminal Code was renewed on 26 September 2004.

\section{Analysis of Data}

The research data obtained through document analysis method were analyzed using content analysis method (Yıldırım \& Şimşek, 2006). The acts of the teachers put on trial were grouped into three categories based on the Turkish Criminal Law no. 5237: "crimes against the person", "crimes against society", and "crimes against the state and the nation". These categories were divided into subcategories as follows:

a) Crimes Against the Person

b) Crimes Against Society

c) Crimes Against the State and Nation

A wide range of criminality is indicated since the law is very comprehensive. Here, the themes were created on the basis of the specific crimes committed by the teachers. In order to ensure the reliability of the study, randomly selected cases re-coded at different times by a research assistant who was studying criminal law. A $90 \%$ consensus was reached when the coding results were compared. A $70 \%$ consensus is required among coders for the reliability of research (Hall Vance \& Van Hauten, 1983). It was concluded that the measurement of illegal act categories in this study was reliable since this percentage was exceeded. A code was assigned to each case in the presentation of the findings (such as D1, D2, D3) and the numbers and the years of the main decisions of the cases were shown in brackets.

\section{Results}

\section{Table 1}

The Distribution of Crimes Committed by Teachers by Year

\begin{tabular}{lc}
\hline Years & f \\
\hline 2004 & 3 \\
2008 & 4 \\
2013 & 2 \\
2014 & 21 \\
2015 & 14 \\
2016 & 9 \\
2017 & 13 \\
\hline Toplam & 66 \\
\hline
\end{tabular}

The distribution of crimes committed by teachers by year is given in Table 1.66 cases related to teachers were found. When the distribution of these cases was analyzed by year, the highest number of cases was in 2014 with 21 cases, followed by 2015 with 14 cases, and 2017 with 13 cases. No cases were found for the years not indicated in the Table 1.

The frequencies of the criminal cases against teachers brought to court between 2004 and 2018 according to the categories are given in Table 2 . 


\section{Table 2}

Criminal Cases against Teachers Brought to Court between 2004 and 2018

\begin{tabular}{lc}
\hline $\begin{array}{l}\text { Cases Submitted to Criminal Courts } \\
\text { A-Crimes against the Person }\end{array}$ & F \\
\hline $\begin{array}{l}\text { 1-Crimes against life } \\
\text { a- Man slaughter }\end{array}$ & $\mathbf{4}$ \\
2-Crimes against physical integrity & $\mathbf{1 7}$ \\
a-intentional injury & $\mathbf{3}$ \\
b-reckless injury & $\mathbf{1 5}$ \\
3-Crimes against sexual inviolability & $\mathbf{2}$ \\
4-Crimes against liberty & $\mathbf{5}$ \\
5-Crimes against honor & $\mathbf{4}$ \\
6-Crimes against private life and private areas of life & $\mathbf{7}$ \\
7-Crimes against Property & \\
B-Crimes against Society & $\mathbf{3}$ \\
\hline 1-Crimes against public safety & $\mathbf{1}$ \\
2-General endangering crime & \\
\hline C-Crimes against the State and Nation & \\
\hline 1-Crimes against the reliability and functioning of the public \\
administration \\
a-Fraud \\
b-Abandonment or default in public service & $\mathbf{2}$ \\
2-Crimes against the judiciary & $\mathbf{1}$ \\
a-Failure to inform the authorities & 66 \\
\hline Total & \\
\hline
\end{tabular}

When Table 2 is examined, it can be seen that 66 criminal cases were brought against teachers due to between 2004 and 2018 according to the www.kazanc1.com and www.LegalBank.com websites. While 57 of these cases consisted of crimes against the person, four of them consisted of crimes against society and five cases consisted of crimes against the nation and state. Four of the crimes against persons constitutedcrimes against life and 24 of them consisted of crimes against physical integrity. Two of the crimes against society consisted of crimes against public safety and one of them was in the "general endangering crimes" category. The cases are examined under the following headings.

\section{Cases Related to Crimes Against the Person}

1- When examining the distribution of cases related to persons, it can be seen that the most frequent cases were those against physical integrity. 17 of these cases involved intentional injury and three of them reckless injury. The following is an example of a case related to intentional injury.

It is reported that the victim was injured by a slap to his ear by the accused teacher. In his interim report, dated 31.10.2008, "pain in the left ear, hyperemia and perforation in the left tympanic membrane" was reported..(D1,E. 2015/31119, K. 2016/9024,T. 11.4.2016).

2- Three cases were found with regard to reckless injury. The following case is an example of reckless injury:

The accused was standing at the entrance to the student's playroom with a tea cup in his hand shortly before midday, the mentally disabled victim $\ddot{O}$ hit the tea cup in the hands of the defendant so that tea poured onto the defendant. (D6 E. 2015/8637 K. 2015/31013). 
3- Fifteen cases of crimes against sexual inviolability were found among crimes against the person. An example isgiven below:

The defendant, who is a classroom teacher, called the 7 year-old victims, who were his students, to the teacher's desk, which was covered with tablecloth. He then committed major child sexual abuse by groping them in such a way that the other students in the classroom could not see when they were sitting normally..(D8 E. 2015/14-21 K. 2016/367)

4- Two cases of crimes against liberty were found among the crimes against the person. An example is given below:

The defendant invited the victim to his home on the date of event and, while in his home, said "I want to kiss you." The victim resisted this, but the accused continued to persistently repeat this statement (D21, E. 2014/4-761 K. 2015/364).

5- Five cases of crimes against honor were found among the crimes against the person. Libel and slander are considered crimes against honor. An example is given below:

The complainant, who is a data preparation and control operator in the District's National Education Directorate, alleged that the accused teacher used slanderous and threatening words towards himself such as "Why did you give up the task? You can't give the task to another person Who do you think you are? (D20, E. 2013/367, K. 2014/15639,T. 7.5.2014).

6- Four cases of crimes against private life were found. An example is given below:

The defendant sent an anonymous and unsigned letter to the constituent on 12 January2011 stating there was an intimate relationship between the complainant, with whom he had previously been engaged,and the constituent who works in the same institution with her (D22,E. 2014/8709,K. 2014/26160,T. 22.12.2014).

7- Crimes against the property involve fraud and aggravated fraud. Seven cases were found in the research. An example is given below:

The defendant, who is a teacher in the [...]Elementary School, suggested that the complainant,wh ohe previously knew, place a bid on the canteen and car park of the [...] High School which would be out fortender...The accused [...] who was acting director in the A.N. Preschool on the date of the crime, allegedly made out false invoices and vouchers and cashed them himself (D30,E. 2014/8974, K. 2017/4596,T. 30.10.2017).

\section{Crimes Against Society}

Crimes against society are examined under two headings, crimes against public safety and general endangering crimes. One case was found for each heading. Examples of cases are given below:

1-General Endangering Crimes

"It was alleged that there was no more evidence than that of a criminal charge against the accused $P .[\ldots]$ It was understood that the accused teacher did not agree with the school's headmaster and, therefore, incited his student $\ddot{O}$ to set fire to the school building in order to punishing the headmaster [...] (D24, E. 2006/8-132,K. 2006/160,T. 13.6.2006).

\section{2- Crimes against Public Safety}

\section{Forgery of Official Documents}

In the prosecutionit was claimed that the accused committed the crime of forgery of official documents by adding to the answer sheets of the students named [...] and [...] in order to inflate the grades of a geometry class in September 2012 ... (D27,E. 2017/4404, K. 2017/9121,T. 19.12.2017). 


\section{Crimes Against the State and Nation}

Crimes against the state and nation are categorized as crimes against the reliability and functioning of the public administration, and crimes against the judiciary. Two cases regarding fraud and two cases regarding abandonment or default in public service were found in crimes against the public administration. Examples are given below:

1- Crimes against the reliability and functioning of the public administration

Fraud and Abandonment or Default in Public Service

The accused [...], who was Acting Director in the A.N. Preschool on the date of crime, allegedly made out false invoices and vouchers and cashed them for himself and other accused persons serving as teacher and assistants in the same school, thus allegedly committing a crime (D30,E. 2014/8974, K. 2017/4596,T. 30.10.2017).

\section{2- Crimes against the judiciary}

Failure to inform the Authorities

With regard to the fact that the accused persons, who are teachers, were absent for one day in accordance with the decision taken by their union, regardless of the occurrence of crimes, for unlawful reasons (D33,E. 2003/1992 K. 2004/7607 T. 15.6.2004.

\section{Discussion, Conclusion and Recommendations}

This study found that crimes against the person were the most common criminal charges brought against teachers between 2004 and 2018. This was followed by crimes against the state and nation and then crimes against society.

Crimes involving intentional injury were the most common crimes against the person, and in this category incidents of violence against students were most common. In one case, as a result of being slapped by his teacher a preschool student experienced bleeding, vomited, and lost consciousness. In another case, the teacher hit the child on his ear and ear damage occurred. Injuries caused by a stick/cane used as a weapon indicate an abuse of power by the teacher.

Although corporal punishment should no longer exist in the educational system, beating and other violent actions are still unavoidable in Turkey. In this study, it was seen that the majority of the cases of teachers in the criminal courts consisted of offences against physical integrity and these acts were carried out intentionally by teachers. Further discussion is needed on beatings and violence against students in the education system, especially as carried out the teachers. Studies generally commend that educational activities related to the subject of the research be increased; however, in this research, the subject is teachers themselves and their use of violence against students. This is an issue of great importance in Turkey, given that most beatings are ignored by families and students and do not become criminal cases. Beatings and violence are difficult to avoid, but such behavior cannot be tolerated and previous measures taken in this regard are insufficient. Although there have been many studies on violence in schools, incidents of violence have still occurred in recent years, and these have made schools far from safe places (MEB, 2015). Violence in school occurs not only between students, or between teachers and students, but also between school administrators and staff (Kızmaz, 2006). This study examined the cases in which criminal charges were brought against teachers. The results show that teachers and administrators use violence in the school.

Yavuz et. al. (2003), in their research with high school students, found that while students experienced physical violence in both the school and family environment, female students primarily experienced domestic violence and male students primarily experienced violence in school. It has been determined that the violence experienced in the school is mostly instigated by teachers.

The violence that the child is exposed to at school can have a negative impact their future life. Students, who perceive the aggressive behavior of their teachers as a normal way of exerting social influence and resolving conflict, can internalize these behaviors through "social learning". Teachers and 
the school staff play an important role in the development of the child's psychological and social skills. While teachers are models for students in helping them gain abilities such as conflict resolution skills, empathy and respect for others, their friends also affect their behaviors by example (Şemin, 2016).

Teachers' behavior towards their students also affects their relationships; a teacher who uses violence will inspire fear in their students rather than respect. This also negatively affect show they communicate. Fear, anger, aggression, low self-esteem, insecurity, communication problems, dislike of authority, and peer relationship problems can be seen in students who are subjected to violence from their teachers, and this can lead to learning problems, which can affect development. This may also cause disorders such as sleep problems, school phobia, depression, and anxiety (Kasapç1, 2016).

The man slaughter files of the teachers were also examined. In one case, the student was exercising for May 19 activities, failed to support himself with his hands and fell onto his neck, eventually dying. As a result of this incident, the teacher was also charged with man slaughter.

This study found that among the charges brought against teachers in the criminal courts, the second most common offenses were crimes against sexual inviolability. Research show that children are most often abused by people they trust most. Other studies support these findings. Türk (2018) conducted research in primary schools and stated that all of the administrators and psychological counselors participating in the research had witnessed sexual harassment of students in primary schools, and that the perpetrators could be students, teachers, and school staff. When the criminal cases brought to court are examined, the results of the studies which determine that sexual harassment towards students are common in schools are revealed in parallel with the results (Türk, 2018). Many sexual harassment behaviors are hidden in schools. Talking about sexuality in patriarchal societies often causes many objections. Therefore, sexual harassment cases are often not discussed (Sexual Education Treatment and Research Association, 2006). Incidents of sexual harassment in the family, and sometimes even in the school environment are hidden. The findings of the study conducted by Turk (2018) support this notion. Sexual harassment occurs in schools worldwide. In the study conducted by Robinson (2006) in Australia, incidents of sexual harassment incidents by boys were not taken seriously and were defined as a joke. Another finding shows that the sexual abuse of male students is a common situation (Chiodo, Wolfe, Crooks, Hughes \& Jaffe, 2009). In his study "Reflections of Ethical and Unethical Behaviors of Teachers and Administrators in the Media", Çetin (2015) revealed a total of 184 unethical behaviors teachers engaged in that were reported in the media. 85 of these cases were sexual harassment incidents against students. These figures seem to support the findings of this research and suggest that measures should be taken against sexual harassment of children in Turkey

The next most encountered offenses were crimes against property. Fraud is considered in this group and charges of fraud were brought to the criminal courts. One teacher introduced himself as a Department Manager in the Directorate of National Education and demanded money from a man to whom he promised to employ his daughter in a school as an assistant. In another case, the accused, who was a teacher in an Elementary School, told a complainant whom he previously knew that the canteen and car park of a high school was going out to tender. The accused said that he was a close friend of Director of National Education of the area, and knew other people in the commission, and, after saying that he could offer a good deal depending on the tender proposal, then received money from the complainant. This study shows that the penalties imposed are not sufficiently deterrent. The study showed that teachers committed offenses against honor as well.

Among the crimes against society, crimes against public safety and general endangering crimes were found. The number of cases was low. As a general endangering crime, it was found that one teacher instigated his student to set fire to a school building because he was angry with the school principal. As a crime against public safety, the teacher who forged official documents can be given as an example.

Among the crimes against the state and nation, crimes against the reliability and functioning of the public administration and crimes against judiciary were found. In this category, cases of fraud, abandonment or default in public service, and failure to inform to the authority cases were identified. In one fraud case, it was seen that the teachers got an additional course fee although they did not participate in the seminar. In his study on teachers and administrators, Çetin (2015) found cases of neglect of duty and negligence involving 11 teachers and 20 administrators reported in the media. 


\section{Recommendations}

Students should be educated. They should be told that their bodies are private and should not allow anyone to touch their body, and that if they are faced with such a situation, it is not their fault. They should be told from whom they can get help in such situations.

Some programs have been implemented around the world to prevent this from happening. These programs generally focus on issues of gender equality in schools, an explanation of the relationship between violence and harassment, dealing with harassment, what to do when harassment is encountered, how and from whom to ask for help. Such programs should also be implemented in Turkey.

The curriculum of Faculties of Education should include courses such as human rights, education law, anger control and conflict management. In this manner teachers awareness of these issues will be increased. This study found that in one case a teacher sat next to one of the students and put his arm around her shoulder. The teacher may perhaps have thought that this behavior demonstrated affection, but it is better for the male teachers not to touch female students in any way. Teachers should be taught that they should not engage in such behavior, even if they are acting in good faith.

Teachers should be more carefully selected. A psychological and personality test could be applied before they assume their duties.

More attention should be paid to this issue and additional research should be conducted.

School counselors should embrace these matters, be particularly sensitive to case of child abuse cases, and intervene immediately.

\section{References}

Alat, Z. \& Türk, H. (2018). İlkokullarda görev yapan idarecilerin ve psikolojik danışmanların öğrencilere yönelik cinsel tacizler hakkındaki deneyimleri ve uygulamaları.[Experiences and Practices of Primary School Principals and Counselors on Sexual Harassment Towards Students], Ege Eğitim Dergisi [Ege Journal of Education], 19(1), 182-208.

Arası, Ş. , Özan, S. Tımbı1, S., Şemin S. \& Kasapçı, O. ( 2016). Öğrencilerin okulda maruz kaldıkları duygusal ve fiziksel şiddet.[Exposure of Students to Emotional and Physical Violence in the School Environment], Research Article Arch Neuropsychiatry, 53, 303-310.

Ayan, S. (2007). Aile içinde şiddete uğrayan çocukların saldırganlık eğilimleri.[Aggressiveness tendencies of the children exposed to domestic violence] Anatolian Journal of Psychiatry, $8,206-214$.

Ayhan, İ.\& Çubukcu, K.M. ( 2007). Suç ve kent ilişkisine ampirik bakış: Literatür Taraması. [Empirical Overview of Crime and City Relationship: Literature] Süleyman Demirel Üniversitesi Sosyal Bilimler Enstitüsü Dergisi, [Süleyman Demirel University Journal of the Institute of Social Sciences], 3 (5), 30-55.

Carney, J.V. (2000). Bullied to death: Perceptions of peer abuse and suicidal behavior during adolescence. School Psychology International, 21, 213-223.

Chiodo, D; Crooks, C; Hughes, R; Jaffe, P; Wolfe, D.A. (2009). Impact of sexual harassment victimization by peers on subsequent adolescent victimization and adjustment: a longitudinal study. Journal of Adolescent Health, 45 (3), 246-252.

Cinsel Eğitim Tedavi ve Araştırma Derneği (2006).[ Sexual Education Treatment and Research Association] Cinsel yaşam ve sorunları.[Sexual Education and problems] Ankara: CETAD.

Cömert, Ö. \& Sevim, Y. (2017). Çocuk ve suç ilişkisinin sosyolojik suç kuramları ile incelenmesi. [Investigation of child and crime with sociological crime theories], Bitlis Eren Üniversitesi Sosyal Bilimler Enstitüsü Dergisi [Journal of Bitlis Eren University Institute of Social Sciences], $6(1), 29-40$.

Çopur, E., Ulutaşdemir, N. \& Balsak, H.( 2015) Çocuk ve suç. Uluslararası Katılımlı III. Çocuk Gelişimi ve Eğitimi Kongresi "Erken Müdahale” [Child and Crime. International Participation 
III. Congress on Child Development and Education "Early Intervention"] http://dergipark.gov.tr/download/article-file/88852

Cullen, F. T. \& Agnew, R. (2003).Criminological theory: Past to present. Los Angeles, CA: Roxberry Publishing Company.

Demirbaş, T. (2016). Kriminoloji.[Criminology] Ankara: Seçkin Publishing.

Demirkasımoğlu, N. \& Çetin, S. K. (2015).Öğretmen ve yöneticilerin etik ve etik dışı davranışlarının basina yansimaları.[Reflections of teachers' and school administrators' ethical and unethical behaviors to the press] Sosyal Ve Beşeri Bilimler Araştırmaları Dergisi.[Journal of social sciences and humanities researches] 34, 95-110.

Doğan, İ. (2011). “Çocuk hakları açısından Türkiye'de çocuk olgusu [child phenomenon in Turkey in terms of children's rights,] Milli Eğitim Dergisi, 151.http://dhgm.meb.gov.tr/yayimlar/dergiler/Milli_Egitim_Dergisi 151/dogan.htm.

Dönmez, A. \& Çubukçu, Z. (2012) İlköğretim okullarında görev yapan öğretmenlerin okuldaki şiddet üzerine görüşleri,[Primary School Teachers Views Of Violence In Schools] Elektronik Sosyal Bilimler Dergisi,[Electronic Journal of Social Sciences]11 (40), 89 - 108.

Dönmezer, S. (1994). Kriminoloji, [Criminology]. İstanbul: Beta Publishing.

Erdemir, N. ( 1988). Hukuk Devleti ve Savunma Hakkı. [State of Law and Right of Defense] Türkiye Barolar Birliği Dergisi [The Journal of Turkish Bar Association], 1, 81-90.

Erkan, R. Bağl1, M. Sümer, F. \& Ünver, M. (2002). Sosyal çevrenin sokak çocukluğuna ve çocuk suçluluğuna etkisi[Influence of Social Environment on Street Childhood and Juvenile Delinquency] http://dergipark.gov.tr/download/article-file/88899.

Göktürk, N. (2016). Suçun yasal tanımında yer alan 'hukuka aykırılık' ifadesinin icra ettiği fonksiyon. [The Function Of The "Illegality" Which Stated In The Legal Definition Of The Offence ], İn̈̈nü Üniversitesi Hukuk Fakültesi Dergisi.[The Journal of İnönü Faculty of Law]7, 407-450.

Gömleksiz, M, Kilimci, S., Vural, R. A., Demir, Ö., Meek K. Ç. \& Erdal, E. (2008). Okul bahçeleri mercek altında: şiddet ve çocuk hakları üzerine nitel bir çalışma. [School Yards Under The Magnifying Glass: A Qualitative Study on Violence and Childrens' Rights]. Ilkögrretim Online.[Elementary Education Online], 7(2), 273-287.

Güllü, İ. (2014). Suç olgusuna teorik ve eleştirel bir yaklaşım.[A Theoretical And Critical Approach To The Fact Of Crime],KMÜ Sosyal ve Ekonomik Araştırma Dergisi [KMÜ The Journal of Social and Economical Researches], 16 (Special Issue I): 104-107.

Güven, O. Ö. (2017). Suçun sosyolojisi ve haber söyleminde temsili,[Sociology of Crime and Its Representation in the News Discourse] Gaziantep University Journal of Social Sciences, 17 (1), 176-195.

Hoşgörür, V. \& Orhan, A. (2017) Okulda zorbalık ve şiddetin nedenleri ve önlenmesinin yönetimi (Muğla Merkez İlçe Örneği). [The Causes of Bullying and Violence at Schools and Managing the Prevention of It (The Sample of Muğla Province)] Bayburt Eğitim Fakültesi Dergisi,[ The Journal of Bayburt Faculty of Education ],12 (24),859 - 880.

Işık, H. (2006).Çocuk suçluluğu ve okullar ile ilişkisi.[Youth crime And Its Relations With Schools]Ahi Evran Üniversitesi Kırşehir Eğitim Fakültesi Dergisi (KEFAD), [Ahi Evran University Kırşehir Faculty of Education] 7(2), 287-299.

Karaman, Y. \& Taşkın, P. ( 2017). Eğitim Hukuku. [Educational Law] Ankara: Siyasal Publishing.

Kızmaz, Z. (2005). Sosyolojik suç kuramlarının suç olgusunu açıklama potansiyelleri üzerine bir değerlendirme. [An evaluation on explaining the potentials of the crime phenomena related to the sociological crime theories] C.Ü. Sosyal Bilimler Dergisi. [C. U. The Journal of Social Sciences ] 29 (2), 149-174.

Kızmaz, Z. (2006). Okullardaki şiddet davranışının kaynakları üzerine kuramsal bir yaklaşım.[A theoretical approach to the roots of violence behaviors at schools ] Cumhuriyet Üniversitesi Sosyal Bilimler Dergisi, [C.Ü. The Journal of Social Sciences ], 30(11), 47-70. 
Mahiroğlu. A. \& Buluç B. (2003). "Ortaöğretim kurumlarında fiziksel ceza uygulamaları" [Physicalnpunishment in secondary education instituations]. Türk Eğitim Bilimleri Dergisi 1/1 [Turkish Journal of Educational Science].

Menteşe. S. (2012) Sosyo-kültürel ve fiziki mekânların çocukların suça yönelme ya da suç işlemeye etkilerinin Van İli Ölçeğinde Araştırması.[The effect of socio-cultural and physical environments on children's gravitation towards crime and juvenile delinquency based on the example of the city of Van ]. Gaziantep University Journal of Social Sciences, 11(4), 1275-1305.

Miller, T. W. Cleyton, R., Miller J. M., Bilyeu. (2000) Violence in schools: Clinical issues and case analysis for high-risk children. Child Psychiatry and Human Development, 30, 255-272.

Özmen, F. \& Küçük, N. (2013). İki ayrı zaman diliminde okulda şiddet durumu. [The Violence Situation At A School In Two Different Time Periods] CBS Sosyal Bilimler Dergisi, [CBS Journal of Social Sciences] 11 (2), 78-96.

Polat, O. (2004), Kriminoloji ve kriminalistik üzerine notlar, [The notes about criminology and criminalistic ], Ankara: Seçkin Publishing.

Roy F. Baumeister Case Western. (1990). Reserve university suicide as escape from self psychological review, 97(1), 90-113.

Sırma, Ö. (2012) Ceza hukukunda hukuka aykırılık. [Contradition to law in criminal law] Fasikül Hukuku Dergisi, 4(29), 15-21.

Smith, D. L. \& Smith, B. J. (2006). Perceptions of violence: The views of teachers who left urban schools. The high School Journal, 89 (3), 33-42.

Soyaslan, D. (1996). Kriminoloji. suç ve ceza bilimleri. [Criminology, crime and punishment sciences]Ankara: Yetkin Publishing.

Uzbaş, A. (2009). Okul psikolojik danışmanlarının okulda saldırganlık ve şiddete yönelik görüşlerinin değerlendirilmesi. [The evaluation of school counselors' opinions about school violence and aggression] Mehmet Akif Ersoy Üniversitesi Eğitim Fakültesi Dergisi, [The Journal of Mehmet Akif Ersoy University Educational Faculty] 9(18), 90-110.

Yıldırım, A. \& H. Simsek (2016). Sosyal bilimlerde nitel araştırma yöntemleri. [Qualitative research design on social sciences], Ankara: Seçkin Publishing.

Yıldırım, A. (2014). Sosyo-kültürel yapı ve suç olgusu arasındaki ilişki: Malatya İli Örneği. [The Relationship between socio- cultural structure and crime phenomenon: The sample of Malatya] KMÜ Sosyal ve Ekonomik Araştırmalar Dergisi [KMU Journal of Social and Economic Research] 16 (Special Issue I), 1-7. 
